\title{
Moult location and diet of auks in the North Sea inferred from coupled light-based and isotope-based geolocation
}

\author{
Katie St. John Glew ${ }^{1, *}$, Sarah Wanless ${ }^{2}$, Michael P. Harris ${ }^{2}$, Francis Daunt ${ }^{2}$, \\ Kjell Einar Erikstad ${ }^{3,4}$, Hallvard Strøm ${ }^{5}$, Clive N. Trueman ${ }^{1}$ \\ ${ }^{1}$ Ocean and Earth Science, University of Southampton, Waterfront Campus, Southampton SO143ZH, UK \\ ${ }^{2}$ Centre for Ecology \& Hydrology, Bush Estate, Penicuik EH26 0QB, UK \\ ${ }^{3}$ Norwegian Institute for Nature Research, Fram Centre, 9296 Tromsø, Norway \\ ${ }^{4}$ Centre for Biodiversity Dynamics, Department of Biology, Norwegian University of Science and Technology, \\ 7491 Trondheim, Norway \\ ${ }^{5}$ Norwegian Polar Institute, Fram Centre, Postbox 6606 Langnes, 9296 Tromsø, Norway
}

\begin{abstract}
Many pelagic seabirds moult their feathers while at sea, which is an energetically costly behaviour. Mortality rates during moult can be high, so spatial and trophic ecology during this critical period is important for understanding demographic patterns. Unfortunately, individual foraging behaviours specifically linked to at-sea moulting are commonly unclear. This paper combines 2 different approaches to geolocation: data from bird-borne geolocation loggers and stableisotope assignment using carbon and nitrogen isotope maps (isoscapes). Coupling 2 geolocation processes allows some uncertainties associated with isotope-based assignment to be constrained. We applied this approach to quantify species-specific foraging locations and individual trophic variability during feather regrowth in 3 sympatric auk populations breeding on the Isle of May, Scotland (common guillemot Uria aalge, razorbill Alca torda and Atlantic puffin Fratercula arctica). Inferred foraging areas during moult differed between species and feather types. Guillemots likely underwent moult within the southern North Sea, razorbills along the east coast of England and into the southern North Sea and puffins off the east coast of Scotland. Estimates of individual trophic position varied considerably within feather types (up to 1 trophic level difference between individuals), among feather types grown during different time periods and across the 3 species, with guillemots consistently foraging at higher trophic positions than razorbills and puffins. Used in combination, these methods better constrain foraging areas during moulting, and provide a technique to explore individual differences and flexibility in foraging strategy, which is valuable information for both seabird conservation and marine spatial planning.
\end{abstract}

KEY WORDS: Isoscape · Trophic ecology · Foraging $\cdot$ Moult $\cdot$ Atlantic puffin $\cdot$ Common guillemot Razorbill

\section{INTRODUCTION}

The widespread use of miniaturised, ring-mounted data loggers that use light levels in conjunction with a time base to provide positional data, has greatly increased our knowledge of important foraging grounds for pelagic seabirds. Tag-based geolocation data are

\footnotetext{
${ }^{*}$ Corresponding author: katie.stjohnglew@soton.ac.uk
}

particularly useful in time periods when birds are away from the breeding colonies, for example by identifying migration routes and locations of wintering hot spots (Guilford et al. 2009, Jessopp et al. 2013, Frederiksen et al. 2016). Birds must replenish feathers to maintain feather function. In marine birds, feather moult typically occurs outside the breeding season

() The authors 2018. Open Access under Creative Commons by Attribution Licence. Use, distribution and reproduction are unrestricted. Authors and original publication must be credited. 
and potentially has major fitness consequences because flight feathers are crucial for long-distance migration, while body feathers play an important role in thermoregulation, particularly for diving species (Daunt et al. 2006). In most alcid species, there is typically one period of the non-breeding season lasting a few weeks when moulting of flight feathers is focussed, known as the main feather moult. At this time, individuals have fewer foraging options, making them less able to cope with adverse environmental conditions or reduced prey availability (Sandvik et al. 2005, Harris et al. 2014). Environmental sensitivity during feather moult is particularly acute in species such as auks and ducks that are flightless while replacing their remiges. Given the increasing pressures on the marine environment from multiple anthropogenic activities, quantification of foraging location and diet whilst birds are moulting is urgently required for effective conservation and marine spatial planning (Grecian et al. 2010, Lewison et al. 2012, JNCC 2015, MMO 2015).

Geolocator-derived data alone cannot identify specific foraging locations during moulting, as individual moult timing is unconstrained and therefore location and foraging behaviours during winter feather moult are relatively poorly known (Sandvik et al. 2005, Harris \& Wanless 2011, Breton \& Diamond 2014). The stable isotope compositions of animal tissues provide a complementary approach for geolocating animals, particularly when combined with isoscapes (spatially explicit predictive maps of isotope ratios derived from process level models of isotope fractionation or distribution; Royle \& Rubenstein 2004, Hobson et al. 2010).

Stable-isotope-based geolocation has been widely applied to migratory terrestrial birds by using well established hydrogen isoscapes (Wunder \& Norris 2008, Wunder 2010, Hobson et al. 2012, 2014). In the marine environment, the ocean is spatially homogenous with regard to hydrogen isotope ratios, so $\delta^{2} \mathrm{H}$ values cannot be used to assign marine animals to a likely geographic origin (Trueman et al. 2012). The isotopic composition of carbon $\left(\delta^{13} \mathrm{C}\right)$ and nitrogen $\left(\delta^{15} \mathrm{~N}\right)$ in phytoplankton varies spatially, largely reflecting differences in the isotopic composition of nutrients and phytoplankton taxonomic composition. Spatial variations in the isotopic compositions of phytoplankton are passed through the food chain to higher trophic level organisms (Jennings \& Warr 2003, Somes et al. 2010, McMahon et al. 2013) and can be used to infer animal movement patterns across marine isotopic gradients (Quillfeldt et al. 2005, Cherel \& Hobson 2007, Cherel et al. 2008, MacKen- zie et al. 2011). In the context of feather moulting in seabirds, the isotopic composition of a regrown feather provides a chemical record of the area from which resources used in feather growth are derived.

To date, the limited number of detailed and spatially explicit, regional and in situ sample-based marine isoscapes (Jaeger et al. 2010, MacKenzie et al. 2014, Radabaugh \& Peebles 2014, Vander Zanden et al. 2015) has limited the application of these techniques in the marine environment. Geolocation using $\delta^{13} \mathrm{C}$ and $\delta^{15} \mathrm{~N}$ ratios of animal tissues is further complicated as the isotopic composition of a consumer's diet reflects both the spatial origin of the prey items and their trophic level. Here, we address this limitation by combining light- and stable-isotope-based geolocation approaches.

Bird-borne data loggers can indicate the general location of an animal at known points in time (with an error on the order of $\pm 200 \mathrm{~km}$; Phillips et al. 2004, Lisovski et al. 2012), whereas $\delta^{13} \mathrm{C}$ and $\delta^{15} \mathrm{~N}$ measurements depict the most likely origin of the resources assimilated during tissue growth and are influenced by both the location of foraging and composition of the diet. Isotope-based geolocation is generally performed by comparing the isotopic composition of a consumer's tissue to a spatial model (isoscape). If the reference isoscape is created using tissues from species other than the species to be assigned, then some form of isotopic offset or calibration is needed (e.g. Bowen et al. 2014, Trueman et al. 2017). Consumer tissues typically have higher $\delta^{15} \mathrm{~N}$ values by ca. $3.4 \%$ and higher $\delta^{13} \mathrm{C}$ values by ca. $1 \%$, relative to their prey (Kelly 2000, Cherel \& Hobson 2007, Ramos \& Gonzalez-Solis 2012). Hence, accurate geolocation using $\delta^{13} \mathrm{C}$ and $\delta^{15} \mathrm{~N}$ values requires prior knowledge of the isotopic difference between the reference isoscape and the measured tissue attributed to differences in tissue composition, trophic level and individual physiology. Individual differences in trophic geography (the location and composition of a consumer's diet; Bird et al. 2018) may, however, complicate the use of a single calibration value applied to all individuals within a population. Population-level isotopic calibration offsets between reference isoscapes and tissues of interest can be estimated if the region of foraging is known a priori. Population average tissue isotopic compositions can be compared to spatially averaged isotope compositions across the known foraging area extracted from isoscapes (Fig. 1). This approach assumes that individual differences in isotopic calibration effects are normally distributed.

Here, we studied individual variation in location and diet during winter moult in 3 species of auks: 


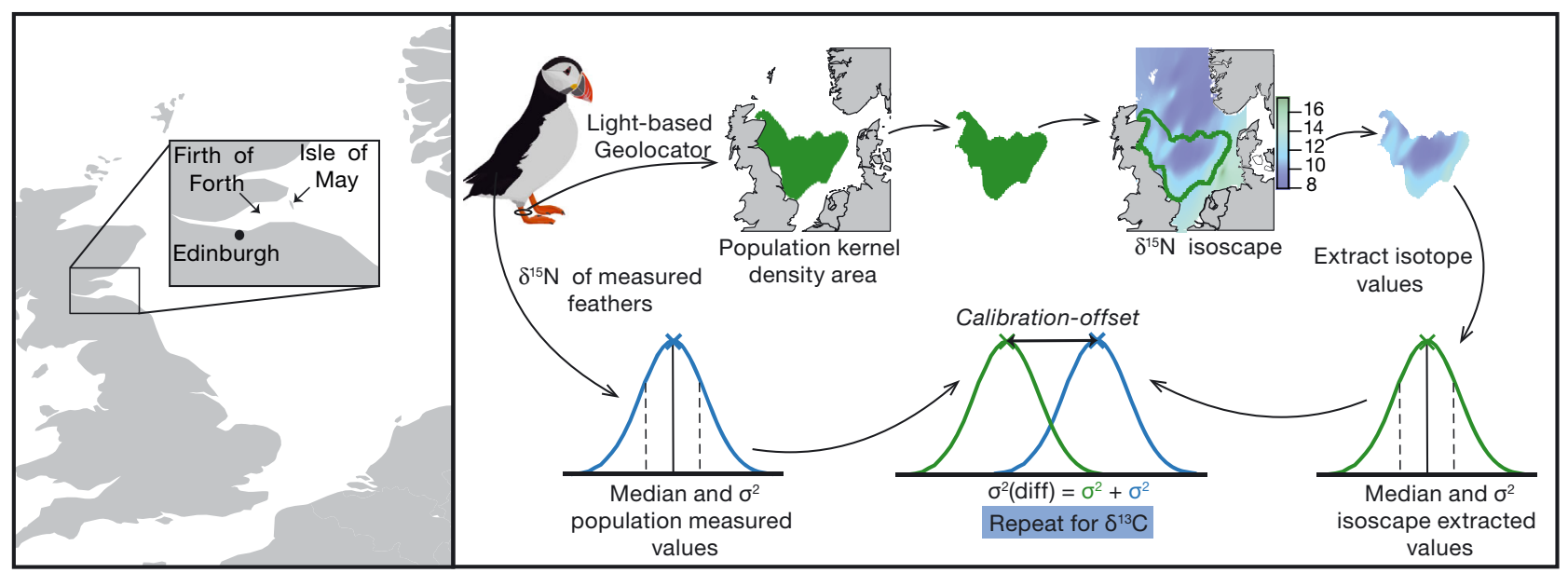

Fig. 1. Location of the Isle of May within the Firth of Forth, SE Scotland, and the methodology used to determine the calibrationoffset value between measured seabird feather isotope values and isoscape isotope values within the overwintering locations indicated by light-based data loggers. This method was repeated for both $\delta^{15} \mathrm{~N}$ and $\delta^{13} \mathrm{C}$ values for all species and feather types

common guillemot Uria aalge (hereafter guillemot), razorbill Alca torda (hereafter razorbill) and Atlantic puffin Fratercula arctica (hereafter puffin) from the Isle of May (Fig. 1), a major colony in the western North Sea. We draw on light-based geolocator data from breeding individuals for which we also had stable isotope data for flight and body feathers. We interpreted isotope data with reference to recently developed $\delta^{13} \mathrm{C}$ and $\delta^{15} \mathrm{~N}$ isoscapes for the North Sea (MacKenzie et al. 2014, Trueman et al. 2017). Our primary aims were to determine population-level foraging locations and quantify individual diet variability during annual moult by combining 2 complementary geolocation techniques.

\section{MATERIALS AND METHODS}

\section{Study area and species}

Fieldwork for this study was carried out on the Isle of May National Nature Reserve, southeast Scotland $\left(56^{\circ} 11^{\prime} \mathrm{N}, 2^{\circ} 34^{\prime} \mathrm{W}\right.$; Fig. 1), which is a major breeding colony for puffins (ca. 40000 pairs), guillemots (ca. 16000 pairs) and razorbills (ca. 3000 pairs) in the western North Sea. Data from ringing recoveries of all 3 species indicate that most individuals from the Isle of May winter and moult within the North Sea (Wernham et al. 2002). However, information from geolocators deployed in the Isle of May colonies indicates that some puffins travel around the north of Scotland into the northeast Atlantic and a single, probably atypical, guillemot had replaced its wing feathers while in the Barents Sea in 3 consecutive winters, while all other guillemots appear to have moulted in the North Sea (Harris et al. 2010, 2015b).

Evidence from beached birds and observations at sea suggest that timing of moult differs somewhat between the species, although information at the colony level is largely lacking (Gaston \& Jones 1998). Guillemots undergo a complete post-breeding moult soon after they leave the colony in July, emerging into the winter plumage when birds have white cheek and neck feathers. The primary wing feathers are shed first followed soon by the secondaries, resulting in birds becoming flightless for between 25 and $80 \mathrm{~d}$ (Thompson et al. 1998), and regrowth is complete by the end of September. In October, birds from the Isle of May immediately start a partial prebreeding moult back into summer plumage when the white feathers of the head and cheek are replaced by dark ones; this moult is completed by the end of December (Harris \& Wanless 1990). Body feathers are not replaced during the pre-breeding moult (Gaston \& Jones 1998). Razorbill moult is similar except that the post-breeding moult starts slightly earlier and the pre-breeding moult starts later so that cheek and neck feathers are not replaced until late winter/early spring, meaning that adults spend several months longer in winter plumage compared to guillemots (Harris \& Wanless 1990, Wernham et al. 2002). Puffins undergo a complete moult of the feathers of the body and head (when the white cheek feathers are replaced by black ones) soon after leaving the colony in mid- to late July. The timing of the replacement of the flight feathers, and hence the flightless period, appears to be much more variable compared to guillemots and razorbills and can occur 
any time between September and March, with peaks in October and March (Harris et al. 2014). The partial pre-breeding moult during which the black feathers of the winter face are replaced by white ones occurs immediately prior to the birds returning to the colony in March (Harris \& Wanless 2011).

Small fish, mainly sandeels (Ammodytidae), juvenile herring Clupea harengus and sprat (Sprattus spp.) and various species of juvenile Gadidae, make up the bulk of the diet of all 3 auks during winter. Some crustaceans, polychaete worms and other pelagic invertebrates are also eaten, with the proportion of invertebrates in the diet appearing to be higher in puffins ( $45 \%$ by biomass) than in guillemots $(<5 \%)$ (Blake 1984, Blake et al. 1985, Sonntag \& Hüppop 2005, Harris et al. 2015a). The limited data available describing winter diet for razorbills in the North Sea suggest that few invertebrates are eaten, but elsewhere crustaceans can dominate the winter diet (Hipfner \& Chapdelaine 2002, Lilliendahl 2009).

\section{Data loggers}

In June and July 2014, breeding birds were caught and each was equipped, under British Trust for Ornithology licence, with a data logger (Migrate Technology, model C250 on guillemots, model C65 on razorbills, model W65 on puffins) attached to a plastic leg ring (combined mass of logger and ring was $<0.4 \%$ of the mass of the adults on which they were deployed). Birds were recaught in June and July 2015, the data loggers were removed and the data downloaded. Details of the field protocols for guillemots and puffins are given in Harris et al. (2010) and Harris et al. (2015b). The methods for razorbills were the same as those for guillemots.

The data loggers measured light intensity at $60 \mathrm{~s}$ intervals and recorded the maximum value in each 10 min interval. This allowed the determination of dawn and dusk which, when linked to a time base, enabled the determination of latitude from the duration of night and day, and longitude from timing of local midnight or mid-day. Details of data-handling and processing are given in Hanssen et al. (2016). Latitudes are unreliable around the equinoxes, so locations during the periods 10 September to 18 October, and 20 February to 5 April were excluded, as were latitudes that were clearly unreliable on visual inspection. The average error of locations has been estimated to be $\pm 200 \mathrm{~km}$ (Phillips et al. 2004), so for birds with coastal distributions many positions occurred over land, but such positions were not filtered out.

To assess usage of the North Sea by each species, temporally specific kernel density maps were produced in R 3.1.2 (R Core Development Team 2016). Kernel density data were subset for each population for the known moulting periods of each feather type (Fig. 2). As secondary feather moult timing of puffins is extremely variable, in this case a kernel density area over the entire winter period was produced. Temporally specific kernel density maps provide a visual representation of the likely location of populations of birds in broadly known moulting

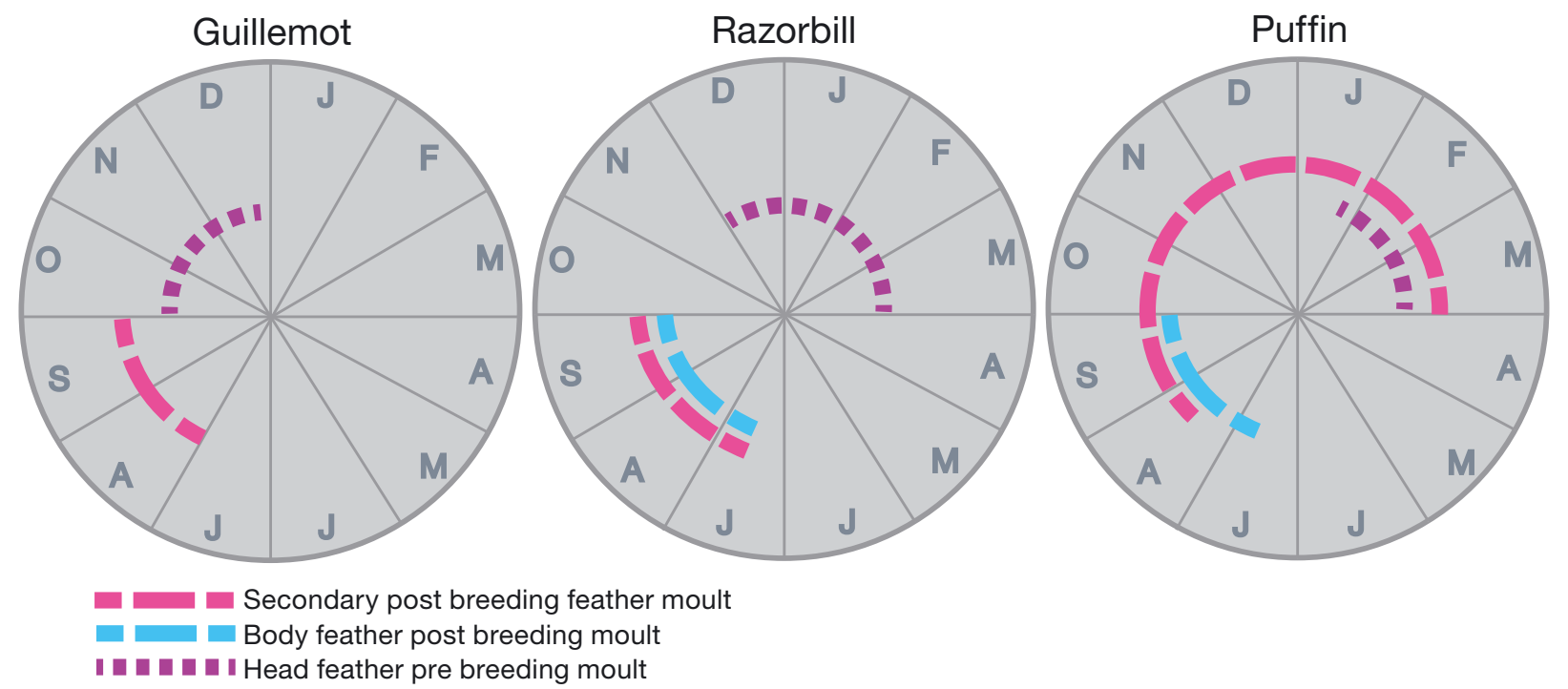

Fig. 2. Graphical representation of assumed moult timings used for subsetting data logger-based geolocation data in guillemots, razorbills and puffins. The prolonged period for secondary moult of puffins is due to the extreme inter-bird variability in the timing of this moult 
seasons throughout the winter, but locations are not necessarily specific to the individual short-term feather moult and/or regrowth periods. Utilization distributions were estimated using kernel density distribution with the 'bkde2d' function in the 'KernSmooth' package (Wand \& Jones 1995). All grid cells (0.1 decimal degrees square) with a population density value greater than 0.01 were interpreted as a possible location, and each cell within this area was given a value of 1 . This was done in order to compare geolocation results with isotopic assignment areas, which represents all likely moulting areas within the isoscape. Individuals with inferred kernel density areas outside the North Sea (1 guillemot secondary feather out of 20 samples, and 1 razorbill cheek feather out of 8 samples) were excluded from the population kernel density areas and the rest of the study, as the isoscape range is currently limited to within this region.

\section{Stable isotope data collection and analysis}

On recapture of each data logger-equipped bird, samples of feathers were collected, under UK Home Office licence. The distal two-thirds of a central secondary wing feather was snipped off each individual. Secondary feathers moult synchronously in the study species, therefore the specific secondary feather sampled was not specified. In addition, 2-5 ventral body feathers and 2-5 head feathers were taken from the sides of the neck (guillemot) or cheeks (puffin and razorbill) (Table 1). Feathers were stored in paper envelopes and deep-frozen until needed.

Feathers were cleaned of surface contaminants using $0.25 \mathrm{M} \mathrm{NaOH}$ and rinsed with milliQ water, dried in a $60^{\circ} \mathrm{C}$ oven for $12 \mathrm{~h}$, then cut into small fragments avoiding the quill and shaft. For secondary, body and neck feathers, only 1 feather sample was analysed per individual; however, cheek feathers were pooled to obtain enough material for analysis. A 0.5-0.7 mg sample was weighed into a tin capsule, and bulk $\delta^{13} \mathrm{C}$ and $\delta^{15} \mathrm{~N}$ values were measured by Elemtex Laboratories (Cornwall, UK).

\section{Population level assignment}

The carbon and nitrogen isoscapes for the North Sea produced by Trueman et al. (2017) were used to assign seabirds to likely foraging areas. Although these isoscapes were produced from samples collected in summer 2015, the spatial distribution of $\delta^{13} \mathrm{C}$ and $\delta^{15} \mathrm{~N}$ values in consumers within the North Sea are relatively stable over time (MacKenzie et al. 2014, Trueman et al. 2017). Seasonal variations in isotopic compositions of primary producers and low trophic level consumers are probable (Kürten et al. 2013) but are likely attenuated during successive predator-prey interactions so that higher trophic level consumers (such as the jellyfish used to construct the isoscape and seabirds) inherit isotopic compositions that reflect a seasonal average value. Therefore, we assumed that the time difference between isoscape construction and collection of bird samples is unlikely to significantly influence geographic assignments at the broad spatial scales considered here. Isotope values for each species and feather type were used to identify a most likely spatial origin within the North Sea using continuous assignment methods following Trueman et al. (2017) and Vander Zanden et al. (2015). Assignments were made by estimating the likelihood that each raster cell of the North Sea carbon and nitrogen isoscapes represented the foraging area of each individual, using the bivariate normal probability function (Vander Zanden et al. 2015, Trueman et al. 2017). Assignment results indicate the likely origin of food resources that the birds used during the period of feather growth. As auks are flightless during flight feather moult, these locations were determined as the likely location of shedding and regrowth of secondaries.

The North Sea isoscape models were derived from jellyfish bell tissues; therefore, a calibration was required to refer the isotope values to bird feathers, accounting for systematic isotopic offsets arising from differences in the amino acid compositions of tissues, and combined effects of trophic level and physiology. Data loggers provided an independent estimate of location from which a population-average calibra-

Table 1. Sample sizes (number of birds) of feathers collected from data logger-equipped birds known to spend the winter within the North Sea. Several feathers of each type were removed from individual birds

\begin{tabular}{|ccccccccc|}
\hline & \multicolumn{3}{c}{ Guillemot } & Razorbill & & Puffin \\
\hline Feather type & Neck & Secondary & Cheek & Body & Secondary & Cheek & Body & Secondary \\
& 18 & 19 & 7 & 9 & 9 & 3 & 12 & 12 \\
\hline
\end{tabular}


tion-offset value was derived for each species and feather type. The calibration-offset value combines any isotopic offset between jellyfish tissue and feather keratin associated with differences in amino acid composition, which is assumed to be consistent across all species and feather types (however, specific alcid offset values have yet to be explicitly determined), and isotopic offsets associated with differences in trophic level between jellyfish and seabirds. Any trophic offset (trophic enrichment factor) may vary among individuals, species and feather types due to differences in diet compositions and diet quality during different time periods. To estimate calibration-offset values, the most likely spatial location of birds at the population level was estimated from light-based geolocation data as the average temporally specific kernel density areas for the population. Population-level likely locations were then overlaid on the carbon and nitrogen isoscapes and spatial average (median and standard deviation) isotope values were extracted at the corresponding coordinates (Fig. 1). Median extracted values represent the $\delta^{13} \mathrm{C}$ and $\delta^{15} \mathrm{~N}$ values the birds would display foraging within these estimated regions during moult if tissue and diet correction factors were not required. By comparing the population median expected values in regions prescribed by light-based geolocation to the population median measured isotope values, population-level calibration-offset values can be estimated (Fig. 1):

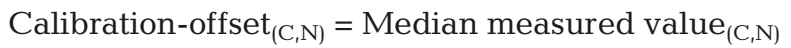
- Median extracted value $_{(\mathrm{C} . \mathrm{N})}( \pm$ error terms) (1)

Combined variance values were calculated by summing the isoscape-extracted isotope variance value and the measured isotope variance value from each feather type and species.

Population-level calibration-offset values were applied to each individual within a population and of the same feather type to compare feather and jelly- fish isotopic compositions. Individual birds were then assigned to likely foraging areas as per Trueman et al. (2017), using assignment conditions summarised in Table 2. A threshold odds ratio was set at 1.42 (representing approximately $70 \%$ of the probability values and $70 \%$ of the isoscape area), meaning any grid cells with a probability value greater than this threshold (the highest $30 \%$ ) were classed as likely, and all other grid cells were classed as unlikely (Trueman et al. 2017). The total number of individual birds assigned to each grid cell was summed for each species and feather type, to depict the most likely population-level foraging locations.

Isotope-based likely foraging locations during moult, and light-based kernel density areas, representing possible locations visited during the assumed seasonal feather moult period, were mapped together. The resulting overlapping locations were inferred as the most likely predicted moult locations based on 2 alternative geolocation techniques.

\section{Isotopic variation among individuals}

Individual differences in foraging behaviour within a population were then investigated to determine the extent of deviation from an average population diet. It was assumed that any isotopic differences associated with the difference in protein compositions between jellyfish and feather proteins are consistent within species and feather types. Thus, individual variability between feather isotopic values within a population moulting in the same region at the same time are assumed to largely represent isotopic differences associated with diet. To assess individual-level foraging behaviour, a similar approach was adopted as used to determine population calibration-offset values (Fig. 1).

Individual-level light-based logger kernel density areas (rather than population kernel density areas) were overlaid on the carbon and nitrogen isoscapes,

Table 2. Assignment conditions adopted for stable isotope-based location of guillemots, razorbills and puffins against isoscapes derived from jellyfish tissue. NA: not applicable for assignment purposes

\begin{tabular}{|c|c|c|c|c|}
\hline \multirow[t]{2}{*}{ Variable } & \multirow[t]{2}{*}{ Isoscape jellyfish } & \multicolumn{3}{|c|}{ Seabird assignment } \\
\hline & & Guillemot & Razorbill & Puffin \\
\hline Measurement error $(\sigma)(\%)$ & $\delta^{13} \mathrm{C} \& \delta^{15} \mathrm{~N}: 0.2$ & \multicolumn{3}{|c|}{$\delta^{13} \mathrm{C} \& \delta^{15} \mathrm{~N}: 0.2$} \\
\hline Between-individual variance (\%o) & $\begin{array}{l}\delta^{13} \mathrm{C}: 0.78 \\
\delta^{15} \mathrm{~N}: 1.02\end{array}$ & $\begin{array}{l}\delta^{13} \mathrm{C}: 0.52 \\
\delta^{15} \mathrm{~N}: 0.91\end{array}$ & $\begin{array}{l}\delta^{13} \mathrm{C}: 0.51 \\
\delta^{15} \mathrm{~N}: 0.58\end{array}$ & $\begin{array}{l}\delta^{13} \mathrm{C}: 0.53 \\
\delta^{15} \mathrm{~N}: 0.56\end{array}$ \\
\hline Calibration-offset and variance values & NA & \multicolumn{3}{|c|}{$\longrightarrow$ Derived — see Table $3-$} \\
\hline Threshold odds ratio & NA & 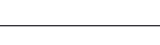 & -1.42 & \\
\hline
\end{tabular}


and the corresponding spatial median and variance isotope values were extracted (Fig. 1). To calculate the expected feather isotope values, the populationlevel isotopic calibration estimate was applied to each individual. If the individual was foraging at the same trophic position as the average value for the population, the expected and extracted isotope values would match. Individual differences in isotopic compositions associated with diet were therefore quantified as:

Ind. expected value ${ }_{(\mathrm{C}, \mathrm{N})}=$ Median extracted ind. value $_{(\mathrm{C}, \mathrm{N})}+$ Pop. calibration-offset ${ }_{(\mathrm{C}, \mathrm{N})}$

Residual ind. variability ${ }_{(\mathrm{C}, \mathrm{N})}=$ Ind. expected value $_{(\mathrm{C}, \mathrm{N})}$ - Ind. measured value $(\mathrm{C,N})$

Residual individual variability measures indicate the deviation of each individual from the average population calibration-offset value, reflecting the range of trophic levels that individuals from the same population are feeding over and any individual variability in isotopic fractionation due to differences in diet quality and physiological stress (McMahon et al. 2015). The extent of residual individual isotopic variability associated with diet within species and feather types were displayed graphically using density histogram plots produced in R 3.1.2 (R Core Development Team 2016).

\section{RESULTS}

\section{Population moult location}

In all species and feather types, the population median isotope-based assignment areas overlapped light-based estimates of likely location during the moulting period, indicating consistency of methods and allowing refinement of the most likely foraging areas during moult (Fig. 3). The refined most likely foraging area, determined from the coupled geolocation approach, shows greater precision in comparison to either geolocation method used alone, as depicted by the reduced surface area (Fig. 3). The guillemots most likely grew their secondary and neck feathers while in the mid- to southern North Sea (Fig. 3a,b). Razorbills also most likely grew cheek feathers in the southern North Sea (Fig. 3c), whereas body and secondary feather moult likely occurred off east England or north of the Firth of Forth (Fig. 3d,e). For puffins, the most likely location of foraging prior to feather moult was off northeast Scotland or east England across all feather types (Fig. 3f-h).

\section{Population and individual level offsets}

Isotopic offsets between jellyfish (j) and feather (f) tissues for carbon $\left(\delta^{13} \mathrm{C}_{\mathrm{f}-\mathrm{j}}\right)$ were relatively similar across all species and feather types, with specific species and feather type calibration-offset values falling within $2 \%$ and ranging between -0.77 and $0.91 \%$ (Table 3, Fig. 4). Guillemot feather isotope values had consistently higher $\delta^{13} \mathrm{C}$ values than jellyfish tissue, whereas puffins had lower $\delta^{13} \mathrm{C}$ values and razorbill feathers showed mixed results (Table 3, Fig. 4). Isotopic offsets between feather keratin and jellyfish bell tissues for nitrogen $\left(\delta^{15} \mathrm{~N}_{\mathrm{f}-\mathrm{j}}\right)$ ranged from $4.53-7.23 \%$. $\delta^{15} \mathrm{~N}_{\mathrm{f}-\mathrm{j}}$ values were highest for guillemots, followed by razorbill cheek feathers. Razorbill body and secondary feathers and all puffin feather types had similar $\delta^{15} \mathrm{~N}_{\mathrm{f}-\mathrm{j}}$ values (Table 3, Fig. 4).

A large degree of residual individual variability in diet-related isotopic compositions was observed within species and feather types (individual $\delta^{13} \mathrm{C}$ values ranged from $0.74-3.13 \%$ and $\delta^{15} \mathrm{~N}$ values ranged from $0.92-3.73 \%$ ), likely representing up to 1 trophic level difference between individuals within a population (Fig. 4). In general, guillemots showed the greatest among-individual residual isotopic variability in both feather types, with greater variability observed in $\delta^{15} \mathrm{~N}$ values. Razorbill and puffin body feathers also displayed greater among-individual residual variation in $\delta^{15} \mathrm{~N}$ values, compared to $\delta^{13} \mathrm{C}$ values, whereas the opposite was observed within secondary feathers (Fig. 4). The small number of individual puffin cheek feather samples prevents reliable interpretation of results.

\section{DISCUSSION}

Both bird-borne data loggers and isoscape assignment geolocation methods produce relatively accurate location and resource origin information with quantifiable degrees of error (Phillips et al. 2004, Trueman et al. 2017), but both methods currently lack precision. Combining the 2 techniques begins to address some of the complications surrounding isoscape assignment, particularly calibration-offsets when the species of interest is different from the organism used to define the isoscape. Combining geolocation approaches may improve assignment precision whilst maintaining accuracy and provides additional information on individual dietary variation during the annual moult. Here, we combined lightbased and stable-isotope-based geolocation methods to compare foraging location and trophic position in 3 


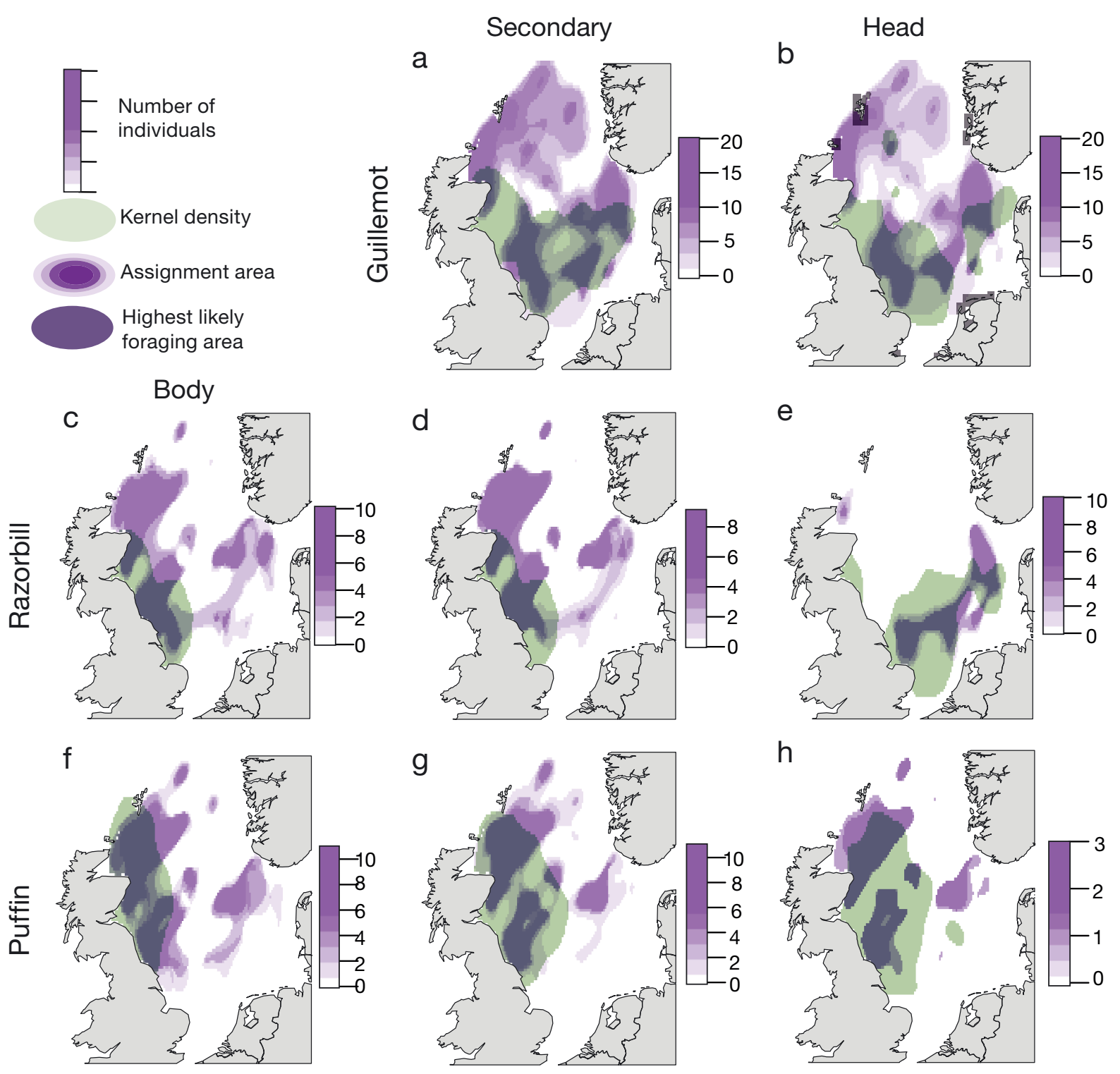

Fig. 3. Population isoscape assignment areas (purple; darker colours indicate more individuals consumed food resources from this area) and corresponding kernel density (green, where density values were $>0.01$ ) areas for the months when moulting of each feather type for each species (guillemots, razorbills and puffins) is known to occur. (a,b) Guillemot secondary and neck feathers, $(c, d, e)$ razorbill body, secondary and cheek feathers; and $(f, g, h)$ puffin body, secondary and cheek feathers. Overlap area, and therefore the highest likely foraging area during feather moult, is indicated in dark violet

Table 3. Population calibration (cal.)-offset values and combined variances calculated from the difference between median extracted isotope values and median measured isotope values for different feather types. Individual (ind.) isotope difference (diff.) values are the difference between individual expected isotope values (individual extracted + population offset) and individual measured values and represent individual diet differences

\begin{tabular}{|c|c|c|c|c|c|c|c|c|}
\hline & \multicolumn{2}{|c|}{ Guillemot -} & \multicolumn{3}{|c|}{-Razorbill__ _ _ _ _ - } & \multirow[b]{2}{*}{ Cheek } & \multirow{2}{*}{$\begin{array}{c}\text { - Puffin } \\
\text { Body }\end{array}$} & \multirow[b]{2}{*}{ Secondary } \\
\hline & Neck & Secondary & Cheek & Body & Secondary & & & \\
\hline$\delta^{13} \mathrm{C}$ cal.-offset (\%o) & $0.75 \pm 1.68$ & $0.47 \pm 1.33$ & $0.91 \pm 1.02$ & $-0.33 \pm 1.07$ & $-0.08 \pm 1.18$ & $-0.2 \pm 0.84$ & $-0.65 \pm 0.98$ & $-0.77 \pm 0.73$ \\
\hline$\delta^{15} \mathrm{~N}$ cal.-offset (\%o) & $7.23 \pm 2.81$ & $6.74 \pm 2.20$ & $6.30 \pm 2.70$ & $4.64 \pm 1.11$ & $4.86 \pm 0.74$ & $5.87 \pm 1.02$ & $4.53 \pm 0.97$ & $5.21 \pm 0.93$ \\
\hline$\delta^{13} \mathrm{C}$ ind. diff. (\%о) & -0.62 to 2.51 & -0.65 to 0.91 & -0.25 to 1.86 & -0.33 to 1.00 & -0.21 to 1.41 & -0.15 to 0.59 & -0.87 to 1.31 & -1.47 to 0.83 \\
\hline$\delta^{15} \mathrm{~N}$ ind. diff. (\%o) & -1.67 to 2.06 & -1.70 to 1.20 & -0.72 to 0.71 & -1.18 to 0.76 & -0.21 to 0.89 & -0.84 to 0.08 & -1.28 to 1.50 & -0.75 to 0.75 \\
\hline
\end{tabular}




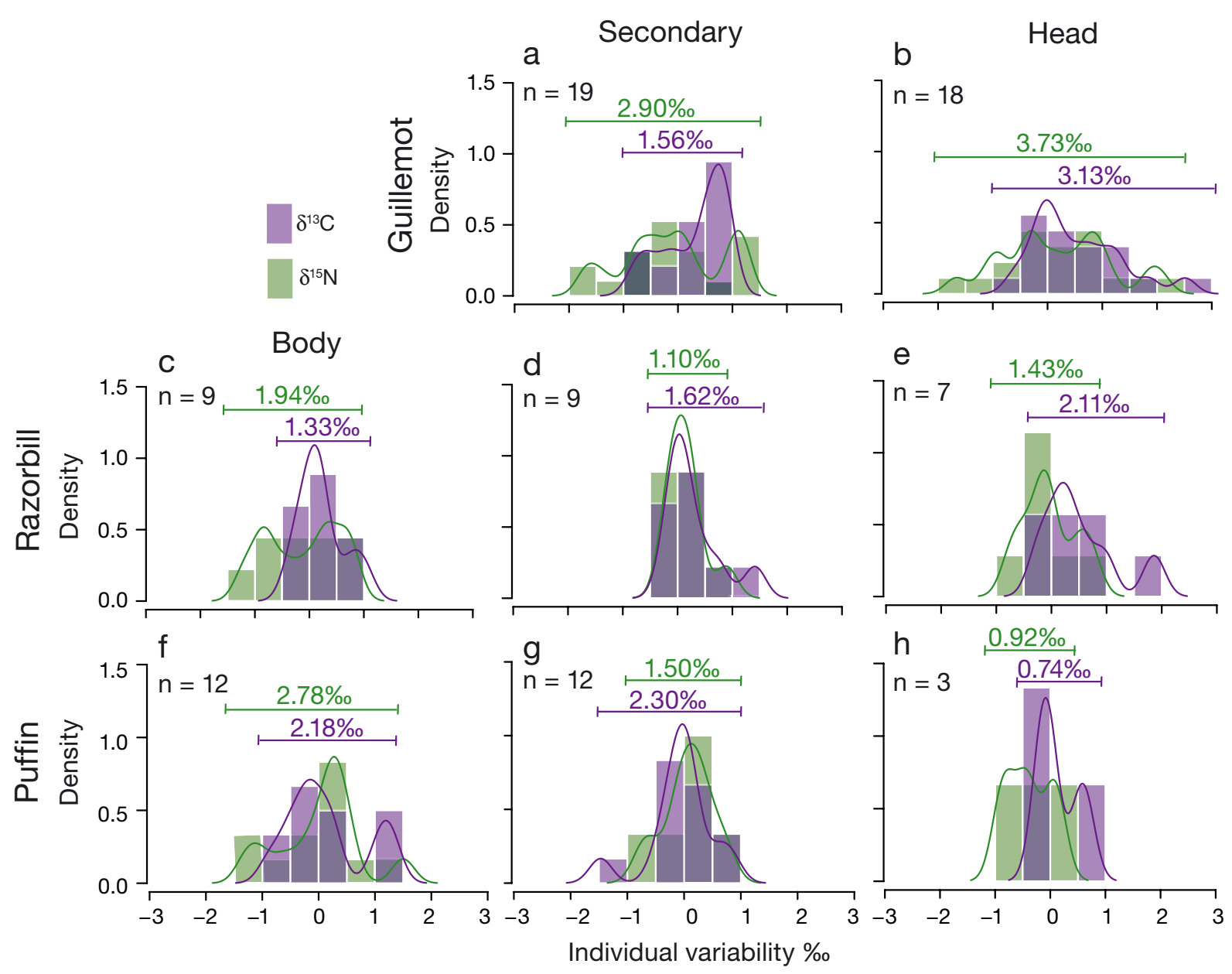

Fig. 4. Individual carbon and nitrogen isotope variability of guillemot, razorbill and puffin feathers displayed in density histograms and corresponding density curves. Individual variability is calculated by determining the difference between the individual expected and measured isotope values, where expected values are individual extracted isotope values plus/minus the population calibration-offset. $(\mathrm{a}, \mathrm{b})$ Guillemot secondary and neck feathers; $(\mathrm{c}, \mathrm{d}, \mathrm{e})$ razorbill body, secondary and cheek feathers; and $(f, g, h)$ puffin body, secondary and cheek feathers. Numbers in green $\left(\delta^{15} \mathrm{~N}\right)$ and purple $\left(\delta^{13} \mathrm{C}\right)$ are the isotope variability ranges for each feather type and species; $\mathrm{n}=$ number of individuals

species of auk while they were growing wing and body feathers. This approach could readily be applied to other populations of seabird that winter in the North Sea and can be fitted with data loggers.

\section{Feeding locations during moult}

The most likely foraging region of Isle of May guillemots during post-breeding secondary feather growth and pre-breeding neck feather growth was in the southern North Sea. This area has previously been identified as a major wintering area for guillemots including those from the Isle of May (Stone et al. 1995, Harris et al. 2015b), but our results emphasise its importance for moulting. To our knowledge, the light-based data logger results presented here are the first for razorbills from a North Sea colony. Taken together with the stable isotope data, they indicate that foraging during the post-breeding body and secondary feather growth most likely occurred in waters off the east coast of England, whereas pre-breeding cheek feather growth primarily occurred in the southern North Sea, suggesting a shift in foraging location during different feather moults. Individual puffin overwintering areas vary greatly, with locations of birds from the Isle of May sometimes extending beyond the North Sea into the northeast Atlantic (Harris et al. 2010, 2013). In our study, puffin foraging areas during moult of individuals that remained in the North Sea were relatively consistent across the 3 feather types, with the most likely foraging areas during autumn and spring restricted to waters off the east coast of Scotland and northeast England. 
Body feathers of pelagic species are not always grown outside the breeding season (Graña Grilli \& Cherel 2017), which could affect interpretation of the results. However, neck and cheek feather moult of these auk species definitely occurs outside the breeding season as indicated by the change in feather colour between the summer and winter plumage. Isotope-based geolocation is currently only possible within the North Sea; a more extensive isoscape is required to investigate foraging location during moult of populations with winter distributions that extend beyond the North Sea into the east Atlantic.

\section{Diet during moult}

In the absence of a dataset of tissue samples from animals from known spatial origins, accurate spatial assignment to an isoscape relies on determining trophic level and tissue offset estimates for each individual and species (e.g. Trueman et al. 2017). In our study, locations of individual auks estimated via light-based data loggers were used to calibrate isotopic offsets between the reference isoscape and feather tissues, and therefore derive population-level (combined tissue and trophic) calibration-offset values. By then assuming that the isotopic contrast associated with differing protein composition of jellyfish bell tissue and species and feather specific keratin is constant, between-individual residual variations in isotopic composition should reflect differences in individual dietary effects.

In general, inferred trophic positions were in line with previous studies of winter diet, i.e. with guillemots feeding at a higher trophic level than razorbills (Blake 1984, Blake et al. 1985). The trophic niche of puffins has been found to decrease from a highly specialised high trophic level diet in summer to a more generalized lower trophic level diet, consisting of more invertebrate prey items, in winter (Hedd et al. 2010, Harris et al. 2015a). Our results add to this picture and suggest that within the North Sea auk community, guillemot, razorbill and puffin populations have different winter diets during different feather moult periods, and trophic level segregation could be a mechanism to reduce interspecific competition outside the breeding season.

The high degree of residual individual variability (Table 3, Fig. 4) between and within feather types and species indicates flexible and generalist diets during the moulting periods. Such flexibility in winter diet has been found in many other species, with individuals also displaying as much as 1 trophic level difference between diets (Phillips et al. 2009, 2017, Young et al. 2010, Grecian 2011). Guillemots were observed to have the greatest residual individual variability, potentially representing a flexible and adaptive winter diet (Blake et al. 1985, Smout et al. 2013). Both puffin and razorbill individuals displayed reduced isotopic residual variability for nitrogen during secondary feather moult, indicating a more uniform population behavioural response during flight feather regrowth. Isotopic residual variability differed between feather types and between species, suggesting different population- and individualscale foraging strategies, during different feather moult time periods. Whilst observed differences in residual isotopic variability seem biologically plausible in terms of dietary differences, variability could also be a result of spatially diverse foraging locations, different body conditions or potentially different melanin content across the different feather types (Michalik et al. 2010, McMahon et al. 2015, Phillips et al. 2017). Further work is needed to clarify these sources of variation.

\section{Method constraints}

Our approach of combining light-based and isotope-based geolocation methods has some limitations. In the absence of sampling constraints, the calibration-offset values for each population and feather type would be calculated from an additional training data set covering the range of all possible locations. However, the volume of data required is beyond the scope of many tracking studies. We recognize that there is circularity in our approach: we used the estimated population-level calibration-offset values to infer location and individual-level diet within the same individuals. In addition, although we have demonstrated an increase in method precision by combining 2 techniques, we are currently unable to explicitly quantify the cost in terms of accuracy. Without a further third, independent measure of individual seabird location, such as satellite or immersion tags (e.g. Cherel et al. 2016), we are unable to quantify the proportion of birds truly undertaking moult within the inferred most likely foraging region, or how this differs from the accuracy achieved for each method alone. As satellite tags become smaller and less expensive to deploy, we suggest further research quantifying the relative cost of accuracy corresponding to the increased precision identified by this technique. 


\section{CONCLUSIONS}

Both bird-borne data loggers and isoscape assignment geolocation techniques have their limitations and associated errors. However, used in combination, they provide a powerful approach to better constrain foraging areas and diet, as well as facilitating exploration of individual differences and flexibility in foraging behaviour during moult. Such information is urgently needed for the North Sea both to inform marine spatial planning decisions, for example the positioning of offshore renewable energy developments, and to develop effective conservation strategies by assessing regions of importance and therefore vulnerability to anthropogenic activities, such as increased fishing efforts.

Acknowledgements. We thank the Scottish Natural Heritage for permission to work on the Isle of May National Nature Reserve; Carrie Gunn and Mark Newell for help with data collection; and SEATRACK (www.seapop.no/en/seatrack/) for funding and logistic support. K.S.G. was jointly funded through the SPITFIRE NERC DTP partnership (grant number 1498919) and SMMI. We thank the Natural Environment Research Council (NERC)/Department for Environment, Food and Rural Affairs (DEFRA) Marine Ecosystems Research Programme (grant number NE/L003082/1) for funding. We also thank Kirsteen MacKenzie and Cefas for the sample collection and initial North Sea isoscape construction, as well as the reviewers and editor for their valuable and constructive feedback.

\section{LITERATURE CITED}

Bird CS, Veríssimo A, Magozzi S, Abrantes KG and others (2018) A global perspective on the trophic geography of sharks. Nat Ecol Evol 2:299-305

Blake B (1984) Diet and fish stock availability as possible factors in the mass death of auks in the North Sea. J Exp Mar Biol Ecol 76:89-103

* Blake B, Dixon T, Jones PH, Tasker M (1985) Seasonal changes in the feeding ecology of guillemots (Uria aalge) off north and east Scotland. Estuar Coast Shelf Sci 20: 559-568

Bowen GJ, Liu Z, Vander Zanden HB, Zhao L, Takahashi G (2014) Geographic assignment with stable isotopes in IsoMAP. Methods Ecol Evol 5:201-206

Breton AR, Diamond AW (2014) Annual survival of adult Atlantic puffins (Fratercula arctica) is positively correlated with herring (Clupea harengus) availability. Ibis 156:35-47

* Cherel Y, Hobson KA (2007) Geographical variation in carbon stable isotope signatures of marine predators: a tool to investigate their foraging areas in the Southern Ocean. Mar Ecol Prog Ser 329:281-287

* Cherel Y, Le Corre M, Jaquemet S, Ménard F, Richard P, Weimerskirch H (2008) Resource partitioning within a tropical seabird community: new information from stable isotopes. Mar Ecol Prog Ser 366:281-291

* Cherel Y, Quillfeldt P, Delord K, Weimerskirch H (2016)
Combination of at-sea activity, geolocation and feather stable isotopes documents where and when seabirds moult. Front Ecol Evol 4:3

* Daunt F, Afanasyev V, Silk J, Wanless S (2006) Extrinsic and intrinsic determinants of winter foraging and breeding phenology in a temperate seabird. Behav Ecol Sociobiol 59:381-388

* Frederiksen M, Descamps S, Erikstad KE, Gaston AJ and others (2016) Migration and wintering of a declining seabird, the thick-billed murre (Uria lomvia), on an ocean basin scale: conservation implications. Biol Conserv 200:26-35

Gaston AJ, Jones IL (1998) The auks: Alcidae. Oxford University Press, Oxford

Graña Grilli M, Cherel Y (2017) Skuas (Stercorarius spp.) moult body feathers during both the breeding and inter breeding periods: implications for stable isotope investigations in seabirds. Ibis 159:266-271

Grecian WJ (2011) Factors influencing the marine spatial ecology of seabirds: implications for theory, conservation and management. PhD thesis, University of Plymouth

Grecian WJ, Inger R, Attrill MJ, Bearhop S, Godley BJ, Witt MJ, Votier SC (2010) Potential impacts of wave powered marine renewable energy installations on marine birds. Ibis 152:683-697

* Guilford T, Meade J, Willis J, Phillips RA and others (2009) Migration and stopover in a small pelagic seabird, the Manx shearwater (Puffinus puffinus): insights from machine learning. Proc R Soc B 276:1215-1223

Kanssen SA, Gabrielsen GW, Bustnes JO, Bråthen VS and others (2016) Migration strategies of common eiders from Svalbard: implications for bilateral conservation management. Polar Biol 39:2179-2188

Harris M, Wanless S (1990) Moult and autumn colony attendance of auks. Br Birds 83:55-66

Harris MP, Wanless S (2011) The puffin. T \& AD Poyser, London

Harris MP, Daunt F, Newell M, Philips RA, Wanless S (2010) Wintering areas of adult Atlantic puffins Fratercula arctica from a North Sea colony as revealed by geolocation technology. Mar Biol 157:827-836

*Harris MP, Daunt F, Bogdanova MI, Lahoz-Monfort JJ, Newell MA, Phillips RA, Wanless S (2013) Inter-year differences in survival of Atlantic puffins Fratercula arctica are not associated with winter distribution. Mar Biol 160: 2877-2889

*Harris MP, Wanless S, Jensen JK (2014) When are Atlantic puffins Fratercula arctica in the North Sea and around the Faroe Islands flightless? Bird Study 61:182-192

Harris MP, Leopold MF, Jensen JK, Meesters EH, Wanless S (2015a) The winter diet of the Atlantic puffin Fratercula arctica around the Faroe Islands. Ibis 157:468-479

Harris MP, Wanless S, Ballesteros M, Moe B, Daunt F, Erikstad KE (2015b) Geolocators reveal an unsuspected moulting area for Isle of May common guillemots Uria aalge. Bird Study 62:267-270

*Hedd A, Fifield DA, Burke CM, Montevecchi WA and others (2010) Seasonal shift in the foraging niche of Atlantic puffins Fratercula arctica revealed by stable isotope $\left(\delta^{15} \mathrm{~N}\right.$ and $\left.\delta^{13} \mathrm{C}\right)$ analyses. Aquat Biol 9:13-22

Hipfner J, Chapdelaine G (2002) Razorbill (Alca torda). In: Poole A, Gill F (eds) The birds of North America, No 635. The Birds of North America, Inc., Philadelphia, PA

Hobson KA, Barnett-Johnson R, Cerling T (2010) Using isoscapes to track animal migration. In: West JB, Bowen GJ, Dawson TE, Tu KP (eds) Isoscapes: understanding 
movement, pattern, and process on Earth through isotope mapping. Springer, Dordrecht, p 273-298

Hobson KA, Van Wilgenburg SL, Wassenaar LI, Larson K (2012) Linking hydrogen $\left(\delta^{2} H\right)$ isotopes in feathers and precipitation: sources of variance and consequences for assignment to isoscapes. PLOS ONE 7:e35137

Hobson KA, Wilgenburg SLV, Wesolowski T, Maziarz M, Bijlsma RG, Grendelmeier A, Mallord JW (2014) A multiisotope $\left(\delta^{2} \mathrm{H}, \delta^{13} \mathrm{C}, \delta^{15} \mathrm{~N}\right)$ approach to establishing migratory connectivity in palearctic-afrotropical migrants: an example using wood warblers Phylloscopus sibilatrix. Acta Ornithol 49:57-69

Jaeger A, Lecomte VJ, Weimerskirch H, Richard P, Cherel Y (2010) Seabird satellite tracking validates the use of latitudinal isoscapes to depict predators' foraging areas in the Southern Ocean. Rapid Commun Mass Spectrom 24: 3456-3460

Jennings S, Warr K (2003) Environmental correlates of large-scale spatial variation in the $\delta^{15} \mathrm{~N}$ of marine animals. Mar Biol 142:1131-1140

Jessopp MJ, Cronin M, Doyle TK, Wilson M, McQuattersGollop A, Newton S, Phillips RA (2013) Transatlantic migration by post-breeding puffins: a strategy to exploit a temporarily abundant food resource? Mar Biol 160: 2755-2762

JNCC (Joint Nature Conservation Committee) (2015) Seabird population trends and causes of change: 1986-2015 report. JNCC, Peterborough. http://jncc.defra.gov.uk/ page-3201

Kelly JF (2000) Stable isotopes of carbon and nitrogen in the study of avian and mammalian trophic ecology. Can J Zool 78:1-27

Kürten B, Painting SJ, Struck U, Polunin NV, Middelburg JJ (2013) Tracking seasonal changes in North Sea zooplankton trophic dynamics using stable isotopes. Biogeochemistry 113:167-187

* Lewison R, Oro D, Godley BJ, Underhill L and others (2012) Research priorities for seabirds: improving conservation and management in the 21st century. Endang Species Res 17:93-121

Lilliendahl K (2009) Winter diets of auks in Icelandic coastal waters. Mar Biol Res 5:143-154

Lisovski S, Hewson CM, Klaassen RH, Korner Nievergelt F, Kristensen MW, Hahn S (2012) Geolocation by light: accuracy and precision affected by environmental factors. Methods Ecol Evol 3:603-612

* MacKenzie KM, Palmer MR, Moore A, Ibbotson AT, Beaumont WRC, Poulter DJS, Trueman CN (2011) Locations of marine animals revealed by carbon isotopes. Sci Rep 1:21

MacKenzie K, Longmore C, Preece C, Lucas C, Trueman C (2014) Testing the long-term stability of marine isoscapes in shelf seas using jellyfish tissues. Biogeochemistry 121: 441-454

McMahon KW, Hamady LL, Thorrold SR (2013) A review of ecogeochemistry approaches to estimating movements of marine animals. Limnol Oceanogr 58:697-714

McMahon KW, Thorrold SR, Elsdon TS, McCarthy MD (2015) Trophic discrimination of nitrogen stable isotopes in amino acids varies with diet quality in a marine fish. Limnol Oceanogr 60:1076-1087

Michalik A, McGill RA, Furness RW, Eggers T, van Noordwijk HJ, Quillfeldt P (2010) Black and white-Does melanin change the bulk carbon and nitrogen isotope values of feathers? Rapid Commun Mass Spectrom 24: 875-878
MMO (Marine Management Organisation) (2015) Marine Management Organisation evidence strategy: 2015 to 2020. MMO, Newcastle. www.gov.uk/mmo

* Phillips RA, Silk JRD, Croxall JP, Afanasyev V, Briggs DR (2004) Accuracy of geolocation estimates for flying seabirds. Mar Ecol Prog Ser 266:265-272

* Phillips RA, Bearhop S, Mcgill RA, Dawson DA (2009) Stable isotopes reveal individual variation in migration strategies and habitat preferences in a suite of seabirds during the nonbreeding period. Oecologia 160:795-806

* Phillips RA, Lewis S, González-Solís J, Daunt F (2017) Causes and consequences of individual variability and specialization in foraging and migration strategies of seabirds. Mar Ecol Prog Ser 578:117-150

* Quillfeldt P, McGill RAR, Furness RW (2005) Diet and foraging areas of Southern Ocean seabirds and their prey inferred from stable isotopes: review and case study of Wilson's storm-petrel. Mar Ecol Prog Ser 295:295-304

R Core Development Team (2016) R: a language and environment for statistical computing. R Foundation for Statistical Computing, Vienna

* Radabaugh KR, Peebles EB (2014) Multiple regression models of $\delta^{13} \mathrm{C}$ and $\delta^{15} \mathrm{~N}$ for fish populations in the eastern Gulf of Mexico. Cont Shelf Res 84:158-168

Ramos R, Gonzalez-Solis J (2012) Trace me if you can: the use of intrinsic biogeochemical markers in marine top predators. Front Ecol Environ 10:258-266

* Royle AJ, Rubenstein DR (2004) The role of species abundance in determining breeding origins of migratory birds with stable isotopes. Ecol Appl 14:1780-1788

Sandvik H, Erikstad KE, Barrett RT, Yoccoz NG (2005) The effect of climate on adult survival in five species of North Atlantic seabirds. J Anim Ecol 74:817-831

* Smout S, Rindorf A, Wanless S, Daunt F, Harris MP, Matthiopoulos J (2013) Seabirds maintain offspring provisioning rate despite fluctuations in prey abundance: a multi species functional response for guillemots in the North Sea. J Appl Ecol 50:1071-1079

* Somes CJ, Schmittner A, Galbraith ED, Lehmann MF and others (2010) Simulating the global distribution of nitrogen isotopes in the ocean. Global Biogeochem Cycles 24: GB4019

Sonntag N, Hüppop O (2005) Snacks from the depth: summer and winter diet of common guillemots Uria aalge around the Island of Helgoland. Atl Seabirds 7:1-14

Stone C, Webb A, Barton C, Ratcliffe N and others (1995) An atlas of seabird distribution in north-west European waters. JNCC, Peterborough

Thompson CW, Wilson ML, Melvin EF, Pierce DJ (1998) An unusual sequence of flight-feather molt in common murres and its evolutionary implications. Auk 115:653-669

* Trueman CN, MacKenzie KM, Palmer MR (2012) Identifying migrations in marine fishes through stable-isotope analysis. J Fish Biol 81:826-847

* Trueman CN, MacKenzie KM, St John Glew K (2017) Stable isotope based location in a shelf sea setting: accuracy and precision are comparable to light based location methods. Methods Ecol Evol 8:232-240

* Vander Zanden HB, Tucker AD, Hart KM, Lamont MM and others (2015) Determining origin in a migratory marine vertebrate: a novel method to integrate stable isotopes and satellite tracking. Ecol Appl 25:320-335

Wand MP, Jones MC (1995) Kernel smoothing. CRC Press, Boca Raton, FL

Wernham CV, Toms M, Marchant JH, Clark J, Siriwardena 
G, Baillie SR (2002) The migration atlas; movements of birds of Britain and Ireland. T. \& A.D. Poyser, London Wunder MB (2010) Using isoscapes to model probability surfaces for determining geographic origins. In: West JB, Bowen GJ, Dawson TE, Tu KP (eds) Isoscapes: understanding movement, pattern, and process on Earth through isotope mapping. Springer, Dordrecht, p 251-270

Editorial responsibility: Keith Hobson,

London, Ontario, Canada
Wunder MB, Norris DR (2008) Improved estimates of certainty in stable-isotope-based methods for tracking migratory animals. Ecol Appl 18:549-559

Young HS, McCauley DJ, Dirzo R, Dunbar RB, Shaffer SA (2010) Niche partitioning among and within sympatric tropical seabirds revealed by stable isotope analysis. Mar Ecol Prog Ser 416:285-294

Submitted: October 23, 2017; Accepted: May 3, 2018 Proofs received from author(s): June 29, 2018 